\title{
A Ilustração (Paris, 1884-1892) e a Revista de Portugal (Porto, 1889-1892): diálogos entre projetos editoriais e possibilidades técnicas
}

Tania Regina de Luca*

\section{RESUMO}

O objetivo deste artigo é investigar o contorno original do projeto que resultou na organização da Revista de Portugal, levado a cabo por Eça de Queirós. O periódico foi lançado em 1889 e desempenhou papel de relevo na discussão de questóes estéticas e políticas do seu tempo. Entretanto, menos conhecida é a conjuntura que levou o escritor a decidir-se pela fundação do impresso, as idas e vindas da concepção editorial do mesmo, as intençóes que acabaram por não se concretizar e o fato de a revista A Ilustração, de Mariano Pina, ter se constituído no ponto de partida do empreendimento. A análise deste caso concreto é relevante, pois remete para as múltiplas possibilidades oferecidas pelo mercado de edição de impressos periódicos, então já efetivamente internacionalizado, além de evidenciar o papel desempenhado pelas possibilidades técnicas na definição da natureza de um impresso periódico bem como o duplo caráter do mesmo, a um só tempo mercadoria e instrumento de intervenção no espaço público.

Palavras-chave: Revista de Portugal; A Ilustração; Eça de Queirós; Mariano Pina; edição no século XIX.

\section{ABSTRACT}

The aim of this article is to investigate the origins and characteristics of the first project concerning the Revista de Portugal, carried out by Eça de Queiroz. The periodical was launched in 1889 and played a major role in the aesthetic and political issues of its time. However, little is known about the circumstances influencing the decision to create the periodical, the comings and goings of its editorial conceptions, the intentions that were not accomplished, and the role of the magazine A Ilustração, and its director Mariano Pina, as the point of departure for the venture. The analysis of this real case is important because it shows the multiple possibilities offered by the publishing market, which was already effectively internationalized. It also highlights the impact of technical issues on the

DOI - http://dx.doi.org/10.1590/2237-101X0183405

Artigo recebido em 10 de janeiro de 2016 e aprovado para publicação em 21 de julho de 2016.

* Professora na Universidade Estadual Paulista Julio de Mesquita Filho. São Paulo - SP, Brasil E-mail: trdeluca@uol.com.br. 
definition of a periodical's nature as well as the double character of the product, at once merchandise and instrument for public intervention.

Keywords: A Ilustração; Revista de Portugal; Mariano Pina; Eça de Queiroz; Publishing in the nineteenth century.

\section{RESUMEN}

El objetivo de este artículo es investigar el contorno original del proyecto que ha resultado en la organización de la Revista de Portugal, creada por Eça de Queiroz. El periódico ha sido lanzado en 1889 y tuvo un rol considerable en la discusión de cuestiones estéticas y políticas de su tiempo. Sin embargo, es menos conocida la coyuntura que llevó el escritor a decidirse por la creación del periódico, las idas y vueltas de su concepción editorial, las intenciones que no se concretizaron y el hecho de que la revista A Ilustração, de Mariano Pina, ha sido el punto de partida del emprendimiento. El análisis de este caso concreto es relevante pues remete hacia múltiples posibilidades ofrecidas por el mercado de edición de impresos periódicos, entonces ya efectivamente internacionalizado, además de evidenciar el rol de las posibilidades técnicas en la definición de la naturaleza de un impreso periódico y su doble carácter, al mismo tiempo mercancía e instrumento de intervención en el espacio público.

Palabras clave: Revista de Portugal; A Ilustração; Eça de Queiroz; Mariano Pina; edición en el siglo XIX.

Percorrer as páginas do quinzenário A Ilustração (Paris, 1884-1892) e do mensário Revista de Portugal (Porto, 1889-1892) remete o leitor a mundos bastante distintos. A primeira, como bem indica o seu título, alude a um gênero de impresso que ganhou força na Europa de meados do século XIX, com a incorporação, em grande escala, da imagem; enquanto a segunda, com capa austera e layout próximo do livro, estampava textos densos e de caráter ensaístico, não fazia qualquer concessão ao mundanismo e destinava-se a um público intelectualizado. Vale a pena analisar com mais vagar cada uma dessas publicaçôes.

\section{A sedução da imagem}

As transformaçóes conhecidas no processo de impressão no decorrer da primeira metade do século XIX, que incluíram a introdução da prensa a vapor, a forma cilíndrica, o rolo de papel contínuo, fabricado a partir da celulose, alteraram o patamar vigente nas tipografias desde a invenção de Gutenberg e multiplicaram, em escala até entáo inédita, a produção dos impressos, com repercussão nos preços e na qualidade do que se ofertava ao público. 
Data da década de 1840 o surgimento das revistas autointituladas ilustradas, cujo conteúdo textual e imagético firmava compromissos com a atualidade, bem ao contrário da geração anterior de impressos periódicos que, a despeito de também mobilizar a imagem, pautava-se pelo ideal de difundir conhecimentos úteis. O novo gênero foi inaugurado pelas dezesseis páginas do The Illustrated London News (Londres, 1842), metade das quais ocupadas por material iconográfico, fórmula logo replicada por L'Illustration (Paris, 1843) e por uma série de outras revistas que, nas mais diversas línguas, evocavam o mesmo título, ainda que exibissem diferentes graus de proximidade em relação ao modelo original — Illustrirte Zeitung (Leipzig, 1843), A Ilustração (Lisboa, 1845), Il Mondo Illustrato (Turim, 1846), La Ilustraction Espanola (Madri, 1847), Illustrated News (Nova York, 1853), Ilustração Brasileira (Rio de Janeiro, 1854), para ficar apenas em alguns exemplos. ${ }^{1}$

Note-se que, no interior do amplo rol de impressos periódicos que se valia de ilustraçóes, as revistas anteriormente elencadas constituíam-se um grupo específico, que guardava considerável distância das humorísticas, nas quais a caricatura, em suas diversas modalidades, era o carro chefe, a exemplo do paradigmático Le Charivari (Paris, 1832), Punch (Londres, 1841), com o indicativo subtítulo The London Charivari, ou os lusófonos Suplemento burlesco ao Patriota: folha de caricaturas (Lisboa, 1847), Jornal para rir: semanário cômico, profético e satírico (Lisboa, 1847), O Asmodeu: seminário burlesco e não político (Lisboa, 1856), Semana Ilustrada (Rio de Janeiro, 1860), de Henrique Fleiuss, e Revista Ilustrada (Rio de Janeiro, 1876), de Angelo Agostini. Enquanto esse tipo de publicação ilustrada, ancorada no humor, floresceu no Brasil do Segundo Império, as ilustraçôes inspiradas nas congêneres europeias, com suas belas imagens xilográficas, não prosperaram entre nós, em grande parte pela ausência de mão de obra versada na produção das trabalhosas matrizes. ${ }^{2}$

A falta de perenidade das tentativas registradas na capital do Império é um bom indício das dificuldades enfrentadas, como se observa no elenco formado pela Ilustração Brasileira (1854-1855), O Brasil Ilustrado, publicação literária (1855-1856), Ilustração Brasileira: jornal enciclopédico (1861), Ilustração do Brasil (1876-1880), Ilustração Popular (1876-1877), Ilustraçâo Brasileira: jornal de artes, ciências e letras (1876-1878). É significativo que o único empreendimento longevo tenha sido Ilustração Brasileira (1909-1958), que circulou num momento em que a impressão direta da fotografia já estava disponível e difundida, o que ocorreu somente na passagem do século XIX para o XX. Até esse momento, era preciso transpor o que fora captado pela máquina para outro suporte (madeira, metal ou pedra calcária), de modo a permitir sua incorporação às páginas dos impressos periódicos. ${ }^{3}$

\footnotetext{
${ }^{1}$ Sobre as revistas ilustradas, no registro aqui apresentado, ver: BACOT, Jean-Pierre. La presse illustrée au XIX ${ }^{e}$ siècle. Une histoire oubliée. Limoges: Presse Universitaires de Limoges, 2005.

${ }^{2}$ A respeito da imagem no Brasil do XIX, ver: ANDRADE, Joaquim Marçal Ferreira de. História da fotorreportagem no Brasil. A fotografia na imprensa do Rio de Janeiro de 1839 a 1900. Rio de Janeiro: Elsevier 2004 e SANTOS, Renata. A imagem gravada. A gravura no Rio de Janeiro entre 1808 e 1853. Rio de Janeiro: Casa da Palavra, 2008.

${ }^{3}$ Além das obras citadas na nota anterior, ver: CARDOSO, Rafael. Projeto gráfico e meio editorial nas revis-
} 
Os obstáculos não diziam respeito apenas ao Brasil, onde imperava a escravidão, mas também eram sentidos em Portugal por aqueles que se aventurassem a colocar em circulação um produto similar às ilustraçóes inglesas e francesas, bem acabado e com preços competitivos no âmbito dos mercados locais. Foi justamente o português Elísio Mendes, homem de negócios que vivia entre Lisboa e o Rio de Janeiro e um dos proprietários do jornal $G a$ zeta de Notícias (Rio de Janeiro, 1875), que decidiu explorar esse filão e lançar A Ilustração. Revista quinzenal para Portugal e Brasil, ${ }^{4}$ por aí antever boas possibilidades de lucros. Para tanto, ele dispunha, nos dois lados do Atlântico, de conhecimentos e contatos no mundo dos impressos periódicos e da circunstância de poder contar com um jovem correspondente do seu jornal em Paris, o também português Mariano Pina, ${ }^{5}$ a quem incumbiu de tratar dos aspectos editorais e literários do negócio, enquanto ele respondia pelos custos e pelas questôes propriamente empresariais.

Em maio de 1884, veio a público o primeiro número da nova publicação, que, das máquinas do impressor francês, seguia para os poróes dos navios que se dirigiam a Lisboa e ao Rio de Janeiro, onde estavam os leitores. A partir dessas cidades eram distribuídos, respectivamente, pela Casa David Corazzi, que desfrutava de prestígio no cenário lisboeta e respondia pela edição da Biblioteca do Povo e das Escolas e pelos Dicionários do Povo, coleçôes iniciadas em 1881 e que também eram vendidas no Brasil, pois a casa mantinha, desde 1882, sucursal na Corte, com sede na rua da Quitanda, n. 40, ${ }^{6}$ e pelo prestigioso matutino Gazeta de Notícias, o que é compreensível tendo em vista que um de seus donos era o idealizador e financiador da nova revista, ainda que essa informação nunca tenha sido divulgada aos leitores do jornal. ${ }^{7}$

A prática de produzir periódicos na Europa não era propriamente uma novidade, bastando lembrar o exemplo de Baptiste Louis Garnier, que mandava imprimir na França o seu Jornal das Famílias (Rio de Janeiro, 1863). De fato, desde 1861 contava-se com serviços

tas ilustradas do Segundo Reinado. In: KNAUSS, Paulo; MALTA, Marize; OLIVEIRA, Cláudia; VELLOSO, Mônica Pimenta (Org.). Revista Ilustrada. Modos de ler e ver no Segundo Reinado. Rio de Janeiro: Mauad X; FAPERJ, 2011, p. 17-40.

${ }^{4} \mathrm{O}$ subtítulo manteve-se inalterado no primeiro ano de circulação para oscilar, em 1885, entre A Ilustração. Revista universal impressa em Paris ou simplesmente A Ilustração. Entre dezembro de 1885 e julho de 1887 , adotou-se fórmula próxima do original, A Ilustração. Revista de Portugal e do Brasil, optando-se apenas por A Ilustração daí em diante, procedimento também adotado ao longo do texto.

${ }^{5}$ A respeito da trajetória de Mariano Pina (1860-1899) e de sua atuação como correspondente da Gazeta de Notícias ver: LUCA, Tania Regina de. Correspondente: origens da atividade no Brasil nas décadas de 1870 e 1880. Sobre jornalismo. Revista científica internacional, v. 5, n. 1, jan./jul. 2016. Disponível em: <http:// surlejournalisme.com/rev/index.php/slj>.

${ }^{6}$ Sobre David Corazzi, ver: DOMINGOS, Manuela D. Estudos de sociologia da cultura. Livros e leitores do século XIX. Lisboa: Instituto Português de Ensino a Distância, 1985, p. 11-134. Cumpre notar que, após meados de 1885, o endereço da sucursal foi alterado para rua da Quitanda, n. 38.

${ }^{7}$ A relaçáo entre A Ilustraçấo e o proprietário da Gazeta de Notícias foi estabelecida por MINÉ, Elza. Mariano Pina, a Gazeta de Notícias e A Ilustração histórias de bastidores contadas por seu espólio. Revista da Biblioteca Nacional, Lisboa, v. 7, n. 2, p. 23-61, jul./dez. 1992. 
postais regulares entre a França, Portugal e o Atlântico Sul, a cargo da empresa Messageries Maritimes, que, a partir de Bordeaux, servia os portos de Lisboa, Ilhas Canárias, Dakar, Pernambuco, Bahia e Rio de Janeiro, além de Montevidéu e Buenos Aires. ${ }^{8}$

A impressão da Ilustração estava a cargo das oficinas da Société Anonyme de Publications Périodiques, empresa dotada de sólidos capitais, proprietária de um conjunto diversificado de títulos, que incluía o concorrente direto de L'Illustration, o semanário Le Monde Illustré (Paris, 1857). ${ }^{9}$ O espólio dos irmãos Augusto e Mariano Pina, depositado na Biblioteca Nacional de Portugal, guarda o primeiro orçamento para a Ilustraçáo fornecido pela Société, datado de novembro de 1883, no qual se estabelece que o gênero e o formato da revista seriam idênticos ao do Monde Illustré (16 páginas, com textos e gravuras, 3 colunas, in-4º), além de colocar à disposição da publicação a revenda de material imagético produzido para o periódico da casa:

[...] os clichês que forem selecionados da nossa coleção do Monde Illustré serão cobrados por reprodução em galvanos, quinze centavos o centímetro quadrado; reproduçóes reduzidas fotograficamente para produção de relevo tipográfico, vinte e cinco centavos o centímetro quadrado — já incluídos, nos dois preços, os direitos de reprodução. ${ }^{10}$

O resultado foi um produto graficamente bem acabado, similar ao que circulava nas grandes capitais europeias, e que ostentava o glamour de vir de Paris. Sem rival à altura nos mercados português e brasileiro, era vendido a preços menores do que as publicaçóes da mesma natureza produzidas localmente. ${ }^{11} \mathrm{O}$ fato foi reconhecido pelo artista português Rafael Bordalo Pinheiro, em carta remetida de Lisboa a Mariano Pina, poucos dias após o lançamento do primeiro número da Ilustração:

\footnotetext{
${ }^{8}$ Para o tema, ver: BERNERON-COUVENHES, Marie-Françoise. Les Messageries Maritimes. L'essor d'une grande compagnie de navigation française, 1851-1894. Paris: Presse de l'Université Paris-Sorbonne, 2007.

${ }_{9}^{9}$ Dados sobre a fundação da sociedade, que tinha à frente Paul Dalloz, e suas publicaçôes em: MOLLIER, Jean-Yves. $O$ dinheiro e as letras. História do capitalismo editorial. São Paulo: Edusp, 2010, p. 82-83.

10 "[...] les clichés qui seraient pris par vous dans notre collection du Monde Illustré vous seront comptés pour les reproductions en galvanos quinze centimes le centimètre carré, pour les reproductions réduites photographiquement pour faire un relief typographique vous seront comptés vingt-cinq centimes le centimètre carré - les droits de reproduction tout compris dans ces deux prix.” Biblioteca Nacional, Lisboa, Espólio N17/202. Esta, como todas as demais, são traduçóes livres do autor.

${ }^{11}$ Em Portugal, a assinatura anual da Ilustração custava 2.400 réis, a semestral 1.200, a trimestral 600 e o número avulso 100 réis, bem menos do que se pagava por $O$ Ocidente, publicação do mesmo gênero, contemporânea d'A Ilustração, cujos preços, em maio de 1884, estavam em 3.800 réis (ano), 1.900 (semestre), 950 (trimestre), 120 (exemplar avulso). No Brasil, os leitores da Ilustração despendiam 12 mil réis pela assinatura anual e a metade para a semestral, enquanto nas províncias oferecia-se apenas subscrição anual, no valor de 14 mil réis, montando o número avulso a 500 réis. A título de comparação, citam-se os valores do último número da Ilustração Brasileira (abril de 1878), cuja subscrição anual era de 14 mil réis na Corte e 15 mil nas Províncias, enquanto a semestral estava em 7.500 (Corte) e 8 mil (províncias).
} 
[...] a Ilustração está muito boa, muito elegante e espere-a de certo um êxito larguíssimo, se alguma coisa há a lamentar é não ser impressa em Portugal, para desenvolver e animar estes operários. Mas reconheço que era impossível fazê-la aqui com a mesma facilidade com que se faz em Paris, sobretudo nos novos e lindíssimos processos que hoje estáo reproduzindo desenhos de maneira mais agradável, como os do último número da Ilustração francesa. Voltando à Ilustração, à tua, acho-a ótima e tanto que vou folhear com o maior interesse. ${ }^{12}$
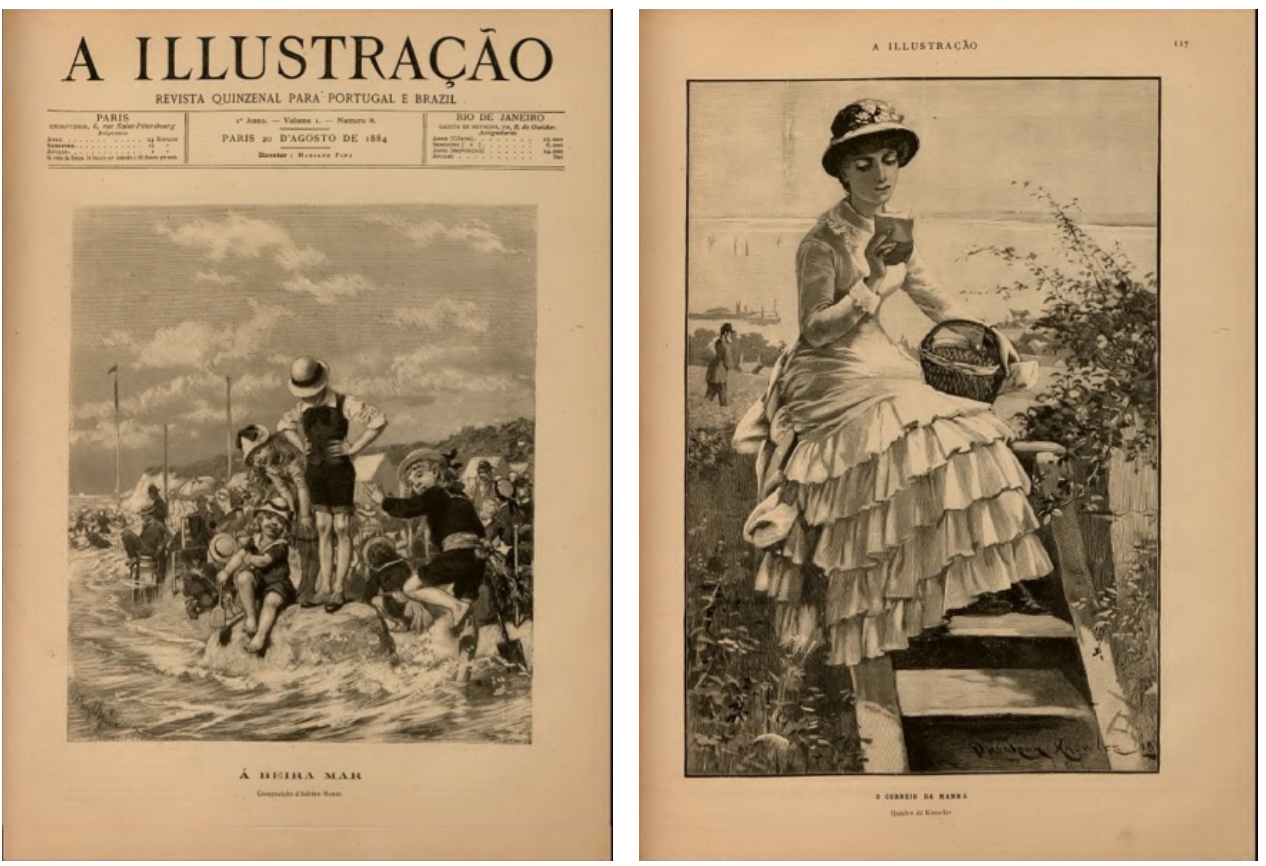

Figuras 1 e 2 - Capa e página interna. A Ilustração, Paris, ano 1, v. 1, n. 8, 20/10/1884. Fonte: Biblioteca da Faculdade de Ciências e Letras, Unesp/Assis.

No último número de 1885, Mariano Pina deixou de figurar como diretor para assumir a condição de diretor proprietário, ou seja, rompiam-se os laços entre A Ilustração, Elísio Mendes e a Gazeta de Notícias, tanto que o matutino fluminense deixou de responder pela distribuição da Ilustraçâa no Brasil, tarefa assumida pela filial da Casa Corazzi no Rio de Janeiro. E não tardou para que também se efetivasse a separação definitiva entre Pina e a Gazeta, ocorrida em 23 de março do ano seguinte por meio de carta lacônica, na qual Elísio dispensava-o das tarefas de correspondente em Paris. A despeito dos rompimentos, a revista continuou a circular até janeiro de 1892, sempre com o jornalista português à testa.

\footnotetext{
${ }^{12}$ Carta de Rafael Bordalo Pinheiro a Mariano Pina, datada de 10/05/1884. Biblioteca Nacional, Lisboa, Espólio N17/163.
} 


\section{A persistência da palavra impressa}

A Ilustração vinculava-se a um setor específico da complexa e diversificada produçấo resultante das modernas prensas e rotativas mecânicas, que se particularizava pela associação entre a imagem e a pena, novidade que representou significativa inflexão na trajetória dos impressos periódicos. Contudo, é óbvio que este fato não implicou no desaparecimento de publicaçôes que não se pautavam pela incorporação da novidade. As chamadas revistas culturais e/ou literárias ${ }^{13}$ tinham outros objetivos e destinavam-se a outro público, disposto a enfrentar o discurso analítico e crítico, marcado pela intertextualidade. Não era raro que se mesclassem, em proporçôes bastante variáveis, produção e crítica literária, debates estéticos, artigos de opinião, relatos de viagens, estudos históricos e geográficos, as últimas novidades provenientes do campo científico. É bom não confundi-las com as publicaçôes especializadas, vinculadas à produção do saber e mantidas por instituiçóes de pesquisa e/ou ensino, que ganharam força na Europa ao longo do século XIX. ${ }^{14}$

Em torno das redações reuniam-se indivíduos que compartilhavam posiçôes estéticas, sociais e/ou políticas e que faziam das revistas um veículo de intervenção no debate público, com a pretensão de "converter as representaçóes comuns, ou afins, em corrente de opiniáo". ${ }^{15}$ Daí a importância dos manifestos-programas e editoriais que explicitavam posicionamentos e permitem cartografar as disputas em curso no campo intelectual. A Revue des Deux Mondes (Paris, 1829) acabou por tornar-se o modelo matricial desse gênero de impresso, ${ }^{16}$ lido, admirado e replicado para além das fronteiras francesas, num momento em que o domínio da língua de Molière nos meios cultos era inconteste.

Não é difícil atestar a influência desta revista no Brasil, que deambulava na mão de personagens de romances, figurava nas bibliotecas públicas e privadas, era referenciada nos

\footnotetext{
${ }^{13}$ Há acordo na bibliografia especializada em distinguir dois grandes grupos de publicaçóes: as revistas de variedades, que se valiam da imagem para seduzir o leitor, e as ditas sérias, que subordinavam o material iconográfico ao texto. A denominação do segundo grupo varia bastante: revistas literárias ou de interesse literário, revistas de cultura, revistas enciclopédicas, revistas de interesse geral, revistas de cultura geral, revistas políticas e literárias, revistas literárias e políticas, enfim as combinaçôes são diversificadas mesmo quando se trata de autores que trabalham os mesmos títulos. Adotou-se a terminologia revistas culturais e/ou literárias, pois o conteúdo político, ainda que sempre presente, raramente se constituía a motivação explícita para o lançamento desse tipo de periódico, que circulou no século XIX e nas décadas iniciais da centúria seguinte. Naturalmente isso não significa que não houvessem revistas com conteúdo programático estritamente político, mas estas, justamente por isso, não integram o rol aqui analisado.

${ }^{14}$ Para o debate em torno da classificaçáo das revistas, ver as ponderaçóes de GESLOT, Jean-Charles; HAGE, Julien. Recenser les revues. In: PLUET-DESPATIN, Jacqueline; LEYMARIE, Michel; MOLLIER, JeanYves (Dir.). La Belle Époque des revues, 1880-1914. Ardenne: Éditions de L’EMEC, 2002, p. 29-42.

${ }^{15}$ ANDRADE, Luís Crespo. Introdução. Quatro notas breves. In: ANDRADE, Luís Crespo (Coord.). Revistas. Ideias e Doutrinas. Lisboa: Livros Horizonte, 2003, p. 12.

${ }^{16} \mathrm{O}$ termo foi cunhado por LOUÉ, Thomas. Un modèle matriciel: les revues de culture générale. In: PLUET-DESPATIN, Jacqueline; LEYMARIE, Michel; MOLLIER, Jean-Yves (Dir.). La Belle Époque des revues, 1880-1914, op. cit., p. 57-68.
} 
textos de especialistas e cujo projeto gráfico e conteúdo inspirou os editores de impressos periódicos. ${ }^{17}$ Ana Luiza Martins referiu-se ao peso da Revue para as congêneres nacionais, desde a Revista Brasileira, nos períodos Nicolau Midosi (Rio de Janeiro, 1879/1881) e José Veríssimo (Rio de Janeiro, 1895/1899), até primeira fase da Revista do Brasil (São Paulo, $1916 / 1925) .{ }^{18}$

Em Portugal, onde não foi menor o impacto da Revue, cabe destacar o exemplo da revista lançada em julho de 1889 por Eça de Queirós, a Revista de Portugal, que fazia eco às publicaçôes culturais e/ou literárias, ainda que a inspiração também fosse tributária de exemplos ingleses, The Fortnightly Review (Londres, 1865) e The Contemporary Review (Londres, 1866), aspecto nem sempre devidamente destacado. ${ }^{19}$ Em março do referido ano, Eça enviou carta circular impressa a diversos periódicos, ${ }^{20}$ acompanhada de alentado prospecto, no qual se listavam os futuros colaboradores, forneciam-se detalhes sobre preço, locais de venda e assinatura e apresentava-se o programa, que ocupava onze páginas e precisava, logo nos parágrafos iniciais, os objetivos do mensário:

Portugal é atualmente na Europa o único país que não possui uma REVISTA - uma publicação onde, além de se apresentarem criações da imaginação no Romance e na Poesia, resultados da investigação na Ciência e na História, trabalhos de Crítica Literária e de Crítica artística, se estudem, com desenvolvimento e adequada competência, os assuntos que genericamente se prendem com a Política, com a Economia, com as Instituições, com os Costumes, com todas as manifestaçōes de um organismo social [...].

Uma revista, organizada conforme o tipo que por toda a parte a popularidade consagrou é uma publicação que oferece nas suas páginas (para enumerar apenas os gêneros mais facilmente classificáveis) produçôes originais no Romance e na Poesia; Crítica literárias, artística e dramática; estudos de História, de Filosofia, de Sociologia, de Economia, de Pedagogia; memórias científicas; biografias; relaçóes de viagem e de costumes; apreciaçóes dos atos legislativos e administrativo; análise dos problemas nacionais; comentários do estado político. Ora todos esses trabalhos, e as ideias, os fatos ou as obras sobre que eles versam, são para o Público de uma importância individual e direta: deles dependem a educação do seu espírito,

\footnotetext{
${ }^{17}$ A respeito da circulação da revista no Brasil, ver: CAMARGO, Katia Aly Franco de. A Revue de sDeux Mondes: intermediária entre dois mundos. Natal: Editora da UFRN, 2007 e DUTRA, Eliana de Freitas. The Revue des Deux Mondes on the context of transatlantic exchanges. In: ABREU, Márcia; SILVA, Ana Cláudia Suriani da. The cultural revolution on the nineteenth century. Theatre, the book-trade, and reading in the transatlantic world. Londres: I. B. Taurus, 2016, p. 121-138.

${ }^{18}$ MARTINS, Ana Luiza. Revistas em revista. Imprensa e práticas culturais em tempos de República. São Paulo (1890-1922). São Paulo: Edusp; Fapesp; Imprensa Oficial do Estado, 2001, p. 75-77.

${ }^{19}$ Sobre o tema, ver o instigante trabalho de COELHO, Teresa Pinto. Londres em Paris. Eça de Queirós e a imprensa inglesa. Lisboa: Ediçóes Colibri, 2010, p. 16-136.

${ }^{20}$ A íntegra da carta circular foi reproduzida em: ANDRADE, Miranda de. Eça de Queirós e a Revista de Portugal. Lisboa: Edições da Revista Ocidente, 1953, p. 30.
} 
por vezes os interesses da sua existência: e o Público é portanto prejudicado quando, pela falta de uma Revista onde esses trabalhos se produzem, não possa aproveitar do ensino, conselho e da luz que eles contenham. ${ }^{21}$

A Ilustraçâo de Mariano Pina deu destaque à boa-nova e publicou excertos do longo programa, além de reproduzir a lista de mais de três dezenas de nome estampados no prospecto e que já haviam prometido "colaboração regular e efetiva", entre os quais figuraram Antero de Quental, Guerra Junqueiro, Jaime Batalha Reis, Oliveira Martins, Pinheiro Chagas, Ramalho Ortigão, Teófilo Braga, além dele próprio. Pina também fez questão de esclarecer aos seus leitores que se tratava de "uma revista mensal, no gênero da Revue des Deux Mondes e da [La] Nouvelle Revue [Paris, 1879]", com vistas a "representar o movimento intelectual do nosso país". ${ }^{2}$

O mensário circulou, com algumas interrupçōes, até maio de 1892, perfazendo 24 números, tendo enfrentado consideráveis dificuldades em sua trajetória, sobretudo em função do diminuto interesse do público (a venda de 3 mil exemplares registrada para o número inaugural estacionou em menos de mil nos subsequentes), ao que se deve acrescer, ainda, a escassez de colaboraçôes, como revela a correspondência de Eça de Queirós. Em várias oportunidades, o escritor registrou seu desalento com os resultados obtidos e os esforços para salvar o projeto, que incluíram mudanças de rumos, conforme ele mesmo anunciou em editorial de outubro de 1890 , que abriu o terceiro volume e no qual se viu forçado a concluir, não sem uma ponta de amargura, que

[...] a única publicação, pois, que a nossa sociedade comporta é um Magazine [...] onde sobretudo predominem as obras de imaginação, as vulgarizaçóes científicas, narraçóes de viagens, os trabalhos biográficos, os estudos de costumes, as atualidades políticas e sociais, toda esta Literatura, ou formas de Literatura, mais adaptadas e próprias para um largo Público, que às ideias e aos fatos nunca pode dedicar um estudo exaustivo, apenas uma fugitiva curiosidade. ${ }^{23}$

\footnotetext{
${ }^{21}$ A íntegra do programa foi publicada no Jornal do Comércio em 14/3/1889 e em O Repórter em 15/3/1889. Posteriormente foi republicado em A Ilustração. Grande revista portuguesa. Lisboa, ano 14, n. 322, p. 12-14, 16/05/1939. Já as informaçóes sobre o prospecto em si estão em COELHO, Teresa Pinto. Londres em Paris. Eça de Queirós e a imprensa inglesa, op. cit., p. 69-70.

${ }^{22}$ Revista das revistas. A Ilustração, Paris, ano 6, v. 6, n. 8, p. 123, 20/4/1889. Quando do lançamento, na seção Bibliografia. A Ilustração, Paris, ano 6, v. 6, n. 15, p. 239, 5/8/1889, noticiou-se o fato nos seguintes termos: "É um lindo volume de 180 páginas, superiormente impresso, tendo todo o aspecto das grandes revistas francesas, como a Revue des Deux Mondes, a [La] Nouvelle Revue ou a [La] Revue de Famille [Paris, 1888] de que é diretor Jules Simon". Os editores Lugan e Genelioux foram saudados pelo apoio a Eça de Queirós, pois, frente à "quadra de mercantilismo literário que atravessamos, não é fácil encontrar quem arrisque capitais em ediçôes que se dirigem unicamente a um público ilustrado, e por consequência bastante diminuto”.

${ }^{23}$ A Revista. Revista de Portugal, Porto, v. III, n. 13, p. VII-VIII, out. 1890.
} 
A despeito da efetivação de algumas das propostas elencadas no editorial, as transformaçôes sofridas pela Revista de Portugal não alteraram de maneira profunda seu escopo e suas características iniciais, que permaneceram distantes da fórmula magazine. Ainda no mesmo editorial, ele não se furtou a tratar do problema da colaboração, subordinando-a às condiçôes literárias e sociais vigentes em seu país. Divisava, de forma precisa, a ausência de um campo intelectual autônomo, capaz de dar concretude aos ideais que motivaram o lançamento da revista. Assim, sem negar a existência de compatriotas competentes, reconhecia que

[...] em Portugal não existia ainda um grupo de escritores que, exclusivamente empregados no exercício das Letras, livres de todas as influências de Partido ou de Escola e disciplinados por hábitos estritamente regulares de trabalho, pudessem assegurar a uma Revista uma colaboração abundante, diligente, variada, oportuna, pontual e eficaz. ${ }^{24}$

Entretanto, cabe destacar que as cartas trocadas com Mariano Pina e com o editor Jules Genelioux indicam que a revista lançada em julho de 1889 era, em vários aspectos, diversa da originalmente imaginada por Eça de Queirós.

\section{Diálogos entre A Ilustração e a Revista de Portugal}

Eça de Queirós e Mariano Pina mantiveram relaçóes de proximidade, que se estreitaram em meados de 1882, momento em que o jovem cronista assumiu o cargo de correspondente da Gazeta de Notícias em Paris, jornal que também contava com a colaboração do escritor desde 1880. Aliás, o tom da carta mais antiga conservada no acervo de Pina, que remonta a julho de 1882, já é despido de formalidades, tanto que o destinatário é tratado por "Meu caro Pina" e, antecedendo o autógrafo, lê-se "Seu do C.[oração]". O texto propriamente dito inicia-se pela frase "Duas palavras à pressa", logo seguida do motivo prático que originou a missiva, qual seja, o fato de Eça não haver encontrado Ferreira de Araújo, redator e coproprietário da Gazeta de Notícias, de passagem por Londres, razão pela qual solicitava que, caso Mariano tivesse o endereço do seu hotel, lhe enviasse. ${ }^{25}$

\footnotetext{
${ }^{24}$ Ibidem, p. VI.

${ }^{25}$ As cartas remetidas por Eça estão conservadas no Espólio de Augusto e Mariano Pina. Biblioteca Nacional, Lisboa, Espólio N17, e várias delas foram publicadas em diferentes coletâneas. Carta de Eça de Queirós a Mariano Pina, datada de 4/7/1882. Eis a íntegra da missiva: "Londres 4 Julho 1882. Meu caro Pina. Duas palavras à pressa. Não encontrei Ferreira de Araújo no Craven Hotel; e como Londres tem mais de mil hotéis, seria pueril a tentativa de o procurar, através da cidade. É natural que ele lhe escreve, e portanto dê a adresse onde estou: se assim suceder, Você faça-me o obséquio amigo de me mandar logo dizer para Bristol, Consulat du Portugal — onde ele enfim se encontra. Não se esqueça Caro Pina, — e boa saúde em Paris! Seu do C.”, grifos no original. Transcrita por FARIA E ALBUQUERQUE, Isabel. Novos contributos para a correspondência de Eça de Queirós. Coimbra: Biblioteca Geral da Universidade de Coimbra, 1992, p. 84.
} 
Apesar de breve, a carta é preciosa, pois evidencia que ambos já se conheciam e é muito provável que os contatos remontassem a janeiro e junho de 1880, quando Eça, que respondia pelo consulado de Bristol, gozou férias em Portugal. Nesse momento, Pina já atuava no cenário jornalístico lisboeta, no qual estreou em 1878 no Diário do Comércio (Lisboa, 1876), tendo logo passado para o Diário da Manhã (Lisboa, 1876), oportunidade em que redigiu diversas notas sobre artes plásticas. Em 1879, manteve acirrada polêmica com Camilo Castelo Branco a propósito do seu Cancioneiro alegre, contenda que lhe deu oportunidade de exaltar As farpas e $O$ primo Basílio, evidenciando a admiração do jovem jornalista por Ramalho Ortigão e Eça. ${ }^{26}$ Ao assumir o prestigioso cargo em Paris, Pina deu um passo importante em sua carreira, que o inseriu na rede transatlântica que unia escritores portugueses e brasileiros e cujo ponto de confluência era o matutino fluminense Gazeta de Notícias. É sintomático que a carta de Eça tenha sido endereçada no momento exato em que Pina se instalava em Paris e que a sua motivação fosse o paradeiro de um dos donos do jornal para o qual ambos escreviam.

No início de 1884, quando Mariano estava às voltas com a organização da Ilustração, ele fez questão de enviar o prospecto para Eça de Queirós, que não se furtou a opinar, aconselhar e colocar-se à disposição para colaborar, além de indicar amigos — "Eu cá estou às ordens para um pequeno artiguinho" - e recomendar outros possíveis interessados "E se V. escrever ao Ramalho [Ortigão], estou certo, que tem prazer nisso. Quando sai a Ilustração?" ${ }^{27} \mathrm{~A}$ promessa foi cumprida e o romancista compareceu com sete textos durante o período de circulação da revista, incluindo o que analisa a influência de Victor Hugo para a sua geração, escrito a pedido do diretor da Ilustração ${ }^{28}$ além de não se furtar à tarefa de amealhar colaboradores. ${ }^{29}$ Contudo, seria simplista restringir sua presença à frieza dos números. $\mathrm{Na}$ seção Crônica, que fazia às vezes de editorial, Mariano Pina referia-se constantemente ao romancista, fosse para elogiá-lo, resenhar suas publicaçôes, defendê-lo, como no caso em que o romance $A$ relíquia foi preterido em concurso promovido em 1887 pela Academia Real das Ciências de Lisboa, ou relatar os encontros que sempre mantiveram quando Eça passava por Paris. Numa dessas ocasiōes, mais precisamente a 3 de maio de 1885, Pina, que poucos dias antes havia visitado Émile Zola, retornou a casa do escritor acompanhado de Eça de Queirós, o que rendeu descriçóes, notas e comentários nas páginas da revista. ${ }^{30}$

\footnotetext{
${ }^{26}$ Para a análise da polêmica, ver: CABRAL, Alexandre. Polemicas de Castelo. Lisboa: Livros Horizonte, 1982, p. 167-187. v. VI.

${ }^{27}$ Carta de Eça de Queirós a Mariano Pina, remetida de Angers, a 26/3/1884. Transcrita por FARIA E ALBUQUERQUE, Isabel. Novos contributos para a correspondência de Eça de Queirós, op. cit., p. 86-87.

${ }^{28}$ QUEIRÓS, Eça. Uma carta sobre Victor Hugo. A Ilustração, Paris, ano 2, v. 2, n. 16, p. 251, 253-254, 20/8/1885.

${ }^{29}$ Carta de Eça de Queirós a Mariano Pina, remetida de Lisboa a 19/8/1884, na qual comunicou que obteve conto inédito do Conde de Ficalho para a Ilustração. Transcrita por REIS, Carlos. Duas cartas inéditas de Eça de Queirós para Mariano Pina. Colóquio/Letras, Lisboa, n. 109, p. 80, maio/jun. 1989.

${ }^{30}$ Ver, por exemplo: PINA, Mariano. Crônica. Eça e Zola. A Ilustração, Paris, ano 2, v. 2, n. 11, p. 162-163, 5/6/1885.
} 
No âmbito privado, as cartas tratavam de questôes literárias, mas também revelam cumplicidade nos pedidos banais, como a encomenda de um frasco de verniz para botas, pois o que fora entregue por Pina no momento da partida de Eça de Paris para Lisboa perdera-se. Em tom de quase desespero, solicitava:

Peço-lhe pois a V. com urgência, e com ardor que me compre um outro frasco, mo meta dentro de uma pequena caixa [...] e mo remeta logo pelo correio," ou, ainda, as instruçóes precisas para a aquisição de um aparelho de ginástica (Régénérateurs musculaires) vendido no Bazar du Voyage, Place del'Opéra. ${ }^{31}$

Pina conservou telegramas enviados por Eça, papéis frágeis, por vezes sem data e que náo continham mais do que uma ou duas frases, mas que testemunham o interesse na convivência íntima:

Caro Pina

Se não tem que fazer apareça por aqui, estou incomodado. Não tenha medo, não há inspeção. Apareça.

Seu do c[oração].

Queirós.

Domingo.

Meu caro Pina. Não parti ontem, e se V. hoje não tiver melhor que fazer, às 7, dê-nos o prazer de aparecer e jantar conosco.

Seu muito dedicado

Queirós. ${ }^{32}$

Indício de que o escritor acompanhava com atenção as consideraçôes de Pina encontra-se em carta remetida de Bristol, a 8 de abril de 1888, na qual Eça reagiu com veemência às observaçóes feitas na Ilustração a respeito de supostos erros de gramática e de sintaxe presentes em suas obras, o que deu origem a uma série de consideraçôes sobre a definição de gramática

${ }^{31}$ Cartas de Eça de Queirós a Mariano Pina, datadas de Angers, 26/7/1884 e 4/3/1884, respectivamente. Transcrita por FARIA E ALBUQUERQUE, Isabel. Novos contributos para a correspondência de Eça de Queirós, op. cit., p. 87 e 85.

${ }^{32}$ Bilhetes postais enviados a Mariano Pina. O primeiro não precisa a data e o segundo, como se depreende do carimbo postal, é de 6/3/1890. Transcritos por FARIA E ALBUQUERQUE, Isabel. Novos contributos para a correspondência de Eça de Queirós, op. cit., p. 92. 
e de sintaxe, além de críticas às passagens do texto de Pina relativas ao tema, consideradas confusas e atrapalhadas. Não se conta com a resposta do jornalista português, mas a julgar pelas observações do reclamante ela deve ter sido bastante extensa e satisfez plenamente o destinatário: "Recebo a sua carta. E gabo-lhe a paciência de ter entrado em tão longas explicaçôes sobre o tal caso gramatical! Está claro que V. não tinha o mínimo desejo de me ser severo! [...]. Em todo o caso, nessas mesmas explicaçôes há amabilidade e simpatia que agradeço". ${ }^{33}$ Foi nessa mesma carta de 5 de junho de 1888 que Eça remeteu instruçóes precisas sobre o deslocamento de Pina a Londres, enquanto na subsequente, remetida dois dias depois, ele perguntava sobre o dia e hora exatos da partida a fim de esperá-lo em Charing Cross. ${ }^{34}$

Os dias que passaram juntos na Inglaterra devem ter sido produtivos, tanto que tomaram a decisão de lançar uma revista, projeto acalentado por Eça desde os tempos de Coimbra, como insistem os seus biógrafos, e que também comparece em seus textos ficcionais. ${ }^{35}$ Pina, por seu turno, acumulava quatro anos de experiência com a Ilustração, que continuava a ser impressa em Paris e de lá remetida para Portugal e o Brasil. A proximidade com o impressor francês era grande, tanto que desde fins de 1885 a redaçáo da revista ocupava duas salas do prédio situado no Quai Voltaire 13, sede da Société Anonymes de Publications Périodiques, que não só imprimia, mas também fornecia, a preços módicos, a grande maioria do material iconográfico nela publicado. Uma primeira menção ao empreendimento, ainda que de forma bastante oblíqua, encontra-se em carta que remeteu de Bristol a Oliveira Martins em 6 de julho de 1888, na qual mencionou brevemente um futuro projeto, sem dar maiores explicaçôes nem mesmo aquele que estava entre os seus amigos mais próximos: "Mariano Pina, que esteve aqui comigo, (e da nossa conversa saiu, ou vai sair, se Deus quiser, uma coisa considerável em que te está marcado um beau rôle)". ${ }^{36}$

Graças à empreitada conjunta, a correspondência com Mariano adensou-se e, no dia 15 de julho, Eça lembrava que estava no aguardo do "resultado das suas [de Pina] indagaçóes na imprensa, etc.", além de opinar, sem grande entusiasmo, a respeito da confecção de um número-modelo, espécie de "amostra do tipo, impressão, etc.", sugerido por Pina e que, na sua avaliação, deveria conter "simplesmente o prospecto, ou uma curta informação das tendências da Revista" ${ }^{37}$ que, a esta altura, ainda não tinha nome definido. As idas ao correio multiplica-

\footnotetext{
${ }^{33}$ Cartas de Eça de Queirós a Mariano Pina, datadas, respectivamente, de Bristol e Londres, 8/4 e 5/6/1888, grifo no original. Transcritas por CASTILHO, Guilherme de (Org.). Eça de Queirós. Correspondência. Lisboa: Imprensa Nacional, Casa da Moeda, 1983, p. 466-468 e p. 477. V. I. O texto que deu origem à questão encontra-se em: PINA, Mariano. Crônica. A Ilustração, Paris, ano 5, v. 5, n. 7, p. 98, 5/4/1888.

${ }^{34}$ Carta de Eça de Queirós a Mariano Pina, remetida de Londres em 7/6/1888. Transcrita por CASTILHO, Guilherme de (Org.). Eça de Queirós. Correspondência, op. cit., p. 478. V. I.

${ }^{35}$ Sobre as revistas imaginadas por Eça, na vida e nas suas obras literárias, consultar: OLIVEIRA, Lopes de. Eça de Queiróz. A sua vida e a sua obra. Lisboa: Ediçóes Excelsior, 1944, p. 243-252. Respeitou-se a grafia do sobrenome de Eça por ter sido a utilizada pelo autor da obra.

${ }^{36}$ Carta de Eça de Queirós a Oliveira Martins, remetida de Bristol em 6/7/1888. Transcrita por CASTILHO, Guilherme de (Org.). Eça de Queirós. Correspondência, op. cit., p. 482-483, V. I, grifo no original.

${ }^{37}$ Carta de Eça de Queirós a Mariano Pina, remetida de Londres em 15/7/1888. Transcrita por CASTILHO, Guilherme de (Org.). Eça de Queirós. Correspondência, op. cit., p. 484. V. I.
} 
vam-se e, por bilhete postal de 22 de julho, comunicava: "Estou a trabalhar no programa da Revista que saiu solene, uma espécie de manifesto! Não tenho porém a certeza de que seja o que convém. Talvez vá muito além, e talvez não diga bastante. Julgo prudente mandá-lo a examinar e criticar Oliveira Martins por muitos motivos. E ele de já lho manda a Você" ${ }^{38}$

Poucos dias depois, a 27 de julho, remeteu de Londres uma longa carta, que retomava os termos do bilhete, para acrescentar que "de reflexão em reflexão, resolvi, poussée par la logique, escrever desde já aos Chardrons! E a carta já partiu”. Vê-se, portanto, que Eça chamava para si as decisóes e, como que para não melindrar o parceiro, indagava: "Não sei se V. ficará descontente de que eu fizesse a proposta, sem ser acompanhada por um número-espécime da Revista”. A justificativa apresentada pelo remetente é importante, pois revela a percepção do escritor em relação aos novos proprietários da casa Chardron, Lugan e Genelioux: "são dous comerciantes que vieram de comércio de raffinerie e cristallerie para o de librairie. A primeira consequência, é que, sendo comerciantes e não livreiros de temperamento, - o que menos lhes importa no livro é o livro. E na Revista o que menos lhes importará é o aspecto material da Revista." Eça resumiu a proposta apresentada que, conforme haviam definido durante a estadia de Pina na Inglaterra, previa a compra da totalidade da edição de cada número por uma casa editora. Mostrou-se satisfeito com os "preços da imprensa" remetidos por Pina, o que permite supor tratar-se dos custos de impressão em Paris. Sobre o programa da revista, Eça prometeu remetê-lo a Pina "logo que o copie mais nitidamente" e esclareceu que não chegara a enviar o material para Martins, tal como anunciara no bilhete postal. ${ }^{39}$

As missivas trocadas entre Eça e Jules Genelioux permitem acompanhar cada passo da negociação. A primeira carta traz a data de 25 de julho e nela Eça apresentou o projeto, ou seja, não consultou ou solicitou a opinião do interlocutor, antes se limitou a dar a conhecer um produto cujas características já estavam estabelecidas. Após constatar a inexistência de uma grande revista em Portugal e no Brasil, esclareceu que a ele cabia o papel de Directeur-en-Chef e a Pina, referido como diretor da Ilustração, o de Directeur-Gérant. ${ }^{40}$ As definições são importantes por explicitarem responsabilidades diversas, uma de ordem intelectual, outra de natureza prática, em consonância com o prestígio desfrutado no mundo intelectual e a competência de cada um. As razóes da presença de Pina ficam evidente à medida que se detalha o projeto: mensário de 120 páginas, no formato da Revue des Deux Mondes, ainda que com um aspecto mais moderno, como fazia questão de frisar o remetente,

\footnotetext{
${ }^{38}$ Bilhete postal remetido de Londres em 22/7/1888. Transcrito por FARIA E ALBUQUERQUE, Isabel. Novos contributos para a correspondência de Eça de Queirós, op. cit., p. 89.

${ }^{39}$ Carta de Eça de Queirós a Mariano Pina, remetida de Londres em 27/7/1888. Transcrita por FARIA E ALBUQUERQUE, Isabel. Novos contributos para a correspondência de Eça de Queirós, op. cit., p. 182-185. Nesta carta Eça emitiu opiniōes pouco lisonjeiras em relação aos demais livreiros portugueses: "Corazzi talvez hesite; Bertrands saiu umas lesmas e comprometiam tudo pela sua incorrigível rotina e inércia; Magalhães \& Monis são escassos de fundos; Pereira é gênero antigo e receia aventuras altas, etc.".

${ }^{40}$ Carta de Eça de Queirós a Jules Genelioux, remetida de Bristol em 25/7/1888. Transcrita por CAETANO, Marcello. Cartas de Eça de Queirós a seus editores (1887-1894). Lisboa: Panorama, 1961, p. 24.
} 
impresso em Paris, pela empresa responsável pela Ilustração, o que era garantia de excelência do papel, da capa, enfim, de todo o produto. Os contatos de Mariano com a Société, a experiência acumulada no trabalho de supervisionar, por anos a fio, a produção de periódico em português por tipógrafos franceses e de acompanhar a remessa dos volumes para os portos de Lisboa e do Rio de Janeiro justificavam o posto de gerente do negócio.

Eça esclarecia que estavam previstas ilustrações, "não em todos os artigos, mas em consonância com a nova moda inglesa, naqueles que reclamam gravuras, como viagens, biografias, criticas de arte etc." ${ }^{\prime 1}$ A tiragem era de 3 mil exemplares, o preço de capa 500 réis e, para o lançamento, estava prevista larga divulgação, que incluía o envio de prospecto a cada assinante da Ilustração, calculados em 6 mil. ${ }^{42} \mathrm{O}$ remetente prometia, para cada edição, conteúdo variado e interessante e apressou-se em anexar não um programa detalhado, mas uma lista de 11 sessóes, espécie de sumário de um número e que permitia antever o espírito da publicação: "I. Artigo de sensação sobre a obra, o fato ou o acontecimento importante do mês; II. Romance, novela ou conto (original, por vezes ilustrado); III. Variedades (biografia, arte, viagens, fantasia, memórias, curiosidade, etc.) ilustrado; IV. Poesia (original); V. O movimento literário, político, científico e social estrangeiro (Paris, Londres, Berlim, Madri, Rio de Janeiro, alternadamente); VI. Variedades (ciências, história, economia, higiene, filosofia, etc., etc.); VII. Crônica política de Portugal; VIII. Romance, novelas, contos (traduzidos dos melhores literatos muito modernos da Inglaterra, Alemanha, Itália, Estados Unidos, etc.); IX. Crônica do luxo e de arte (modas) com ilustraçóes; X. Carta de Portugal para o estrangeiro (crônica de nosso movimento literário, político, mundano, etc.); XI. Bibliografia, crítica, teatros". ${ }^{43}$ Eça concluiu a descrição do projeto com um confiante "tudo está, portanto, decidido," ${ }^{44}$ sem deixar margens para comentários.

É notório que toda a logística de produção estava calcada na experiência da Ilustração, entretanto, como bem indica a lista reproduzida, o conteúdo aproximava a futura revista das

\footnotetext{
${ }^{41}$ Ibidem, p. 24. "[...] non accompagnant tous les articles, mais, à la nouvelle mode anglaise, accompagnant les articles qui réclament des gravures, comme voyages, biographies, critiques d'art, etc.", grifo no original.

${ }^{42}$ Os dados apresentados por Eça estão inflacionados, uma vez que os contratos de impressão da Ilustração estipulavam 4.500 exemplares.

${ }^{43}$ Ibidem, p. 29-30, grifos no original."I. Article a sensation sur l'œuvre, le fait, ou l'évènement important du mois; II. Roman, nouvelle ou conte (originel illustré quelque fois); III. Variété (biographie, art, voyages, fantaisie, mémoires, curiosités, etc.) illustré; IV. Poésie (originelle); V. Le mouvement littéraire, politique, scientifique et social étranger (Paris, Londres, Berlin, Madrid, Rio de Janeiro, tour à tour); VI. Variété (sciences, histoire, économie, hygiène, philosophie, critique, etc. etc.); VII. Chronique politique du Portugal; VIII. Roman, nouvelle, conte (traduits des meilleurs littérateurs très modernes de Angleterre, Allemagne, Italie, États-Unis, etc.); IX. Chronique du luxe et de l'art (modes) avec illustrations; X. Lettre du Portugal pour l'étranger (donnant la chronique de notre mouvement littéraire, politique, mondain, etc.); XI. Bibliographie, critique, théâtres". Com algumas alteraçôes, acréscimos e desdobramentos, que não alteram substancialmente o conteúdo, foram esses itens que figuraram no programa-prospecto, remetido aos órgãos de imprensa em março de 1890 e reproduzido por vários jornais. Na versão final, cada item foi diligentemente descrito, comentado e justificado.

${ }^{44}$ Ibidem, p. 25. "Tout est donc décidé."
} 
congêneres de cunho literário e/ou cultural, mas sem deixar de incorporar, de maneira seletiva e criteriosa, a imagem. $\mathrm{O}$ modelo ficava a meio caminho entre o mundanismo elegante da Ilustração e a dureza das publicações sérias.

Na sequência, o escritor explicitava o que ainda restava para concretizar a empreitada: contar com uma casa editora que se encarregasse da compra e venda da edição. E como um bom negociante que não deseja demonstrar muito interesse na barganha, declarava ter "três ou quatro meios em vista, ${ }^{345}$ mas na condição de diretor sentia-se no dever de consultar primeiro aqueles que publicavam os seus livros, sem esquecer de solicitar total discrição sobre o assunto. Caso se interessassem pelo negócio, a casa editora de Genelioux e Lugan receberia, a cada mês, a edição pronta, ou seja, caberia aos diretores organizar o volume, obter colaboração, tratar da impressão e despachar a publicação para o Porto, pelo que receberiam um montante pela totalidade da tiragem. Sem rodeios, Eça perguntava: "Qual é a comissão que os senhores desejam ou o preço que estão dispostos a pagar por volume vendido a 500 réis" ${ }^{46}$ Vê-se, portanto, que a existência da projetada publicação ancorava-se na venda da edição, sem contar com aportes econômicos de indivíduos ou instituiçóes e tampouco seus idealizadores pretendiam assumir o seu financiamento, procedimentos comuns nas pequenas revistas vanguardistas. Os anúncios chegaram a ser citados como uma possibilidade de renda, mas não entraram, de fato, na contabilidade. ${ }^{47}$

Desde o encontro no início de junho em Londres, quando decidiram lançar um periódico, os acontecimentos precipitaram-se rapidamente, tanto que no mês seguinte o plano havia saído do papel, em grande parte pela decisão de Eça de consultar imediatamente os seus editores, testemunho da prioridade dada à questão. $\mathrm{O}$ mês de agosto de 1888 foi determinante para os rumos do empreendimento, que acabou se concretizando de modo diferente do imaginado. Para recompor os fatos, conta-se com três cartas de Eça a Pina, datadas de 8, 12 e 15, e outras duas a Genelioux, de 17 e 29. Entretanto, outro evento decisivo ocorreu no dia 28 desse agitado mês: o sonho de Queirós de deixar a Inglaterra concretizou-se com a publicação de decreto nomeando-o para o consulado de Paris.

A correspondência com Pina revela surpresas, pois o interlocutor mostrou-se muito menos atilado comercialmente do que o escritor. Enquanto o diretor da Ilustração insistia em quão fundamental teria sido enviar um número de amostra, com boa dose de ironia, Eça ponderava: "Oh, meu caro Pina, no estado inicial desta empresa, que importa a homens de negócios, como os sucessores de Chardron, o saber qual é a cor da capa da Revista, e quantos

\footnotetext{
45 Ibidem, p. 25. "Nous avons trois ou quatre moyens en vue."

${ }^{46}$ Ibidem, p. 26." [...] quelle est la commission que vous voulez ou les prix que vous êtes disposé à payer par volume de 500 réis."

${ }^{47}$ Ibidem, p. 27. "J'oublie de dire que la Revue aura des pages, en papier différent, destinées aux annonces. Un avantage pour les éditeurs." "Esqueci de mencionar que a Revista terá páginas em papel diferente, destinadas aos anúncios. Uma vantagem para os editores." O tema foi retomado na carta seguinte, datada de 17/8/1888. Ibidem, p. 34, na qual Eça assegurou que a revista Ilustração, de Mariano Pina, amealhava 400 francos somente com os anúncios de Paris.
} 
centímetros tem de altura o volume? Oh poeta!...”. De forma lapidar, lembrava ao interlocutor que os editores queriam saber

[...] que garantia dáo os fundadores da Revista; que poder de atrair o leitor tem os que nela colaboram; qual é a sensibilidade do mercado, neste momento, relativamente a publicaçôes por assinatura; que capital é necessário para fazer rolar; quantas vezes no ano é possível fazer passar esse capital; que comissão há a dar aos intermediários; qual será a facilidade da cobrança no Brasil. Como está o câmbio; etc. etc. etc., por aí adiante, no campo sempre dos cálculos práticos, dos cálculos de negócio. ${ }^{48}$

E o acerto das ponderaçôes era comprovado pelo fato de os aspectos materiais, que tanto pareciam preocupar Mariano, não terem sido mencionados pelos editores, circunstância que Eça fez questáo de destacar antes de anunciar ao sócio a resposta que lhe chegara do Porto. Os editores interessavam-se pelo negócio, mas não estavam dispostos a fechá-lo nos termos propostos, ou seja, pagamento de valor fixo pela integralidade da edição. Antes de tudo seria necessário verificar, na prática, o desempenho da publicação, razão pela qual propunham um ensaio por quatro meses, período em que custos e lucros seriam divididos entre os diretores e os editores. Note-se que não lhes importava o aspecto físico e tampouco o conteúdo, tratava-se de testar o produto, analisar as suas potencialidades financeiras, tanto que tratavam, de forma nua e crua, a revista enquanto uma mercadoria que deveria cumprir sua principal razão de ser, gerar bons lucros.

Aliás, não era diferente a postura de Eça ao resumir os termos do acordo, tanto que perguntava: "São porém as condições dessa associação favoráveis para nós?” A carta de Genelioux não lhe parecia suficientemente explícita e assaltavam-no dúvidas: os editores dividiriam todas as despesas (impressão, papel, expedição e colaboração)? Nesse arranjo, os lucros auferidos dependiam da venda efetiva dos exemplares, diferentemente do que ocorria se a ediçáo fosse paga ao ser entregue. Ele mostrava-se confiante na venda de 2 mil exemplares, que "asseguram largamente todas as despesas" e, não sem uma ponta de ingenuidade, julgava que "nas nossas mãos [dele e de Pina] está o não começar a coisa antes de termos 2.000 assinaturas, ou 1.500, deixando 500 para a venda avulsa". Extraía mesmo um imperativo moral da situação, que os obrigaria a "procurar fazer belos números, para que eles se vendam". E instava o sócio a se pronunciar e, caso concordasse, que escrevesse e lhe remetesse um prospecto para ser fundido ao que havia escrito, para "fixar um bom programa, viável, sério e prático". ${ }^{49}$

O tom da carta era positivo e expressava a clara intenção de fechar o negócio. A missiva seguinte traz a data de 12 de agosto, sinal de que Mariano foi rápido na resposta que, con-

\footnotetext{
${ }^{48}$ Carta de Eça de Queirós a Mariano Pina, remetida de Londres, em 8/8/1888, grifo no original. Transcrita por FARIA E ALBUQUERQUE, Isabel. Novos contributos para a correspondência de Eça de Queirós, op. cit., p. 186. ${ }^{49}$ Ibidem, p. 188-189, grifo no original.
} 
tudo, deve ter levantado senôes. O primeiro deles questionava a divisão equitativa dos lucros entre editores e diretores e propunha a fórmula um terço e dois terços, respectivamente, mantendo-se o rateio idêntico das despesas. Eça rechaçou com veemência a proposta, pois se eles eram dois, Genelioux e Lugan também formavam uma dupla e, lucidamente, lembrou que "fazer um negócio dividindo igualmente as despesas — mas dividindo desigualmente os lucros, é coisa que nunca se viu em affaires! [...]”. E, quase já sem paciência, repreendia-o: "Você, que diabo, não viu o negócio comercialmente! Está claro que o trabalho de quem escreve é de outra ordem, superior ao trabalho de quem vende; mas, Você decerto não quer aduzir essa razão de filosofia, que não tem cabimento em negócios de librarie ${ }^{50}$ Concordou com as ponderaçôes do sócio no que dizia respeito à comissão paga aos livreiros, distribuidores e correios que, segundo Pina, poderia chegar a $25 \%$, mas não se deu por vencido e, com grande senso prático, preparou quatro balancetes, sintetizados no Quadro 1, segundo os quais, mesmo incluindo os intermediários, a associação com a casa editora do Porto afigura-se vantajosa, exceção feita à quarta coluna e, assim mesmo, por montante ínfimo.

\section{Quadro 1}

Balancetes elaborados por Eça de Queirós (em mil réis)

\begin{tabular}{|c|c|c|c|c|}
\hline $\begin{array}{c}\text { Tiragem/Forma de } \\
\text { venda }\end{array}$ & $\begin{array}{c}\text { 2.000/Compra } \\
\text { da edição por } \\
\text { editora }\end{array}$ & $\begin{array}{l}2.000 / \text { Associação } \\
\text { com casa editora }\end{array}$ & $\begin{array}{l}\text { 3.000/ Compra da } \\
\text { edição por editora }\end{array}$ & $\begin{array}{l}\text { 3.000/Associação } \\
\text { com casa editora }\end{array}$ \\
\hline Total das Despesas & $\begin{array}{c}949.000 \\
\text { Impressão, re- } \\
\text { dação, gravuras, } \\
\text { transporte, } 40 \% \\
\text { de comissão ao } \\
\text { editor }\end{array}$ & $\begin{array}{c}799.000 \\
\text { Impressão, re- } \\
\text { dação, gravuras, } \\
\text { transporte, } 25 \% \\
\text { comissão aos } \\
\text { livreiros, distri- } \\
\text { buidores } \\
\end{array}$ & $\begin{array}{c}1.216 .500 \\
\text { Impressão, re- } \\
\text { dação, gravuras, } \\
\text { transporte, } 40 \% \\
\text { de comissão ao } \\
\text { editor }\end{array}$ & $\begin{array}{c}991.500 \\
\text { Impressão, re- } \\
\text { dação, gravuras, } \\
\text { transporte, } 25 \% \\
\text { comissão aos li- } \\
\text { vreiros, distribui- } \\
\text { dores } \\
\end{array}$ \\
\hline $\begin{array}{c}\text { Receita, exemplar } \\
\text { a } 500\end{array}$ & 1.000 .000 & 1.000 .000 & 1.500 .000 & 1.500 .000 \\
\hline $\begin{array}{c}\text { Lucro de cada } \\
\text { diretor }\end{array}$ & 25.500 & 50.250 & 141.750 & 127.125 \\
\hline
\end{tabular}

Fonte: Carta de Eça de Queirós a Mariano Pina, remetida de Londres em 12/8/1888.

O único problema é que, de forma muito otimista, Eça sempre dava como certa a venda de toda a ediçấo. Chegou mesmo a pensar em propor que os editores não cobrassem 25 , mas $15 \%$ de taxa, o que aumentaria ainda mais a parte reservada aos diretores. Com o destinatário, insistia: "meu querido Mariano, suplico-lhe que se aplique a ver o negócio só comercialmente e não literariamente e de pena na mão, fazendo cifras!". Não sem um certo desalento, era forçado a concluir que "pelas cifras que tenho feito, já estamos longe da ilusão

\footnotetext{
${ }^{50}$ Carta de Eça de Queirós a Mariano Pina, remetida de Londres, em 12/8/1888, grifo no original. Transcrita por CASTILHO, Guilherme de (Org.). Eça de Queirós. Correspondência, op. cit, p. 499-505. V. I.
} 
meridional das primeiras conversas", explicitando que a motivação de ambos para lançar a revista era auferir lucros. Sempre atento aos custos, começava a ter dúvidas em relação ao modelo que haviam desenhado: "me parece que os preços de imprensa são altos, e que, pelo mesmo preço, teríamos a Revista impressa em Portugal, poupando tempo transporte, ida e vinda de provas, etc. Mas disto só posso julgar em presença de cifras que não tenho presentes. Responda logo". ${ }^{11}$ Os cálculos precisam o ponto de vista dos idealizadores da publicação, que imaginavam destinar $40 \%$ da receita para quem se dispusesse a desempenhar o papel de editor. Vale notar que a publicação continuava referida pelo gênero (revista), não tendo ainda nome próprio.

Antes mesmo de esta carta chegar ao seu destinatário, Eça recebeu outra de Pina, cujo tema central não era a revista, mas a notícia da difícil situação política em que se encontrava o cônsul português em Paris. $\mathrm{O}$ assunto muito o interessava, tanto que ele apressou-se em agradecer, em resposta datada de 15 de agosto, ao "verdadeiramente de bom amigo", ponderando que "a ida para Paris era excelente - mesmo sob o ponto de vista da Revista. Há outra e forte garantia de sucesso. A concentração de serviços na revista é infinitamente para desejar" e cobrava resposta sobre a proposta dos editores, não sem recomendar, ainda uma vez, que Pina o fizesse "com olho nos números!". 52

A possibilidade de ir para a capital do Hexágono empolgou Eça, que, no mesmo dia, também escreveu ao amigo Oliveira Martins, inquirindo sobre a disposição do governo em relaçáo ao Visconde de Faria, ocupante do cargo que tanto almejava. Depois de destacar o quanto poderia contribuir com o país, expôs, sem rodeios, os planos relativos à revista, que havia apenas mencionado na carta já citada de 6 de julho de 1888. Vários aspectos chamam a atenção, a começar pelo fato de Mariano Pina não ser sequer mencionado, era Eça que se apresentava como responsável pelo projeto de uma grande publicaçáo, "nas proporçóes da Revista dos Dois Mundos". Os aspectos financeiros, que dominavam a correspondência com Pina e Genelioux, foram silenciados em prol dos objetivos e do alcance da empreitada, apresentada como "obra de caráter nacional", com largo sentido, que atuava no sentido de reforçar a sua demanda:

Eu desejo fazer dessa publicação, querendo Deus, uma verdadeira obra nacional, colaborada por tudo o que há de melhor, em todas as especialidades, e mostrando enfim que Portugal não é tấo estúpido como por aqui se pensa. Demais a revista seria o órgão dos nossos interesses, perante e Europa, porque uma parte destinada a essa funçáo seria em francês, e por engenhoso sistema, a Revista penetraria em todas as chancelarias da Europa, e nos gabinetes de todos os homens importantes desde Bismarck até ao Papa! Há dois meses que isto se estuda: a casa

\footnotetext{
${ }^{51}$ Idem, grifo no original. Os balancetes encontram-se anexos à carta.

${ }^{52}$ Carta de Eça de Queirós para Mariano Pina, remetida de Londres em 15/8/1888. Transcrita por CASTILHO, Guilherme de (Org.). Eça de Queirós. Correspondência, op. cit, p. 506-508. V. I.
} 
Chardron vê aí un bon succès d'argent; eu creio que se podia fazer disto uma coisa importante e patriótica [...]. Por enquanto basta dizer que, além de todos os motivos que sempre tive para desejar Paris - tenho este a mais; porque, mesmo que a impressão da Revista passasse para Portugal, para simplificar, une grande partie de sa cuisine devrait être faite à Paris. ${ }^{53}$

Nas linhas que destinou a Oliveira Martins, os interesses monetários foram relegados à alçada da casa editora, enquanto o escritor estava às voltas com outras preocupaçóes, de natureza intelectual e patriótica. Crescia a importância estratégica da publicação enquanto defensora dos interesses de Portugal, tanto que a revista, que continuava sem nome próprio, contaria com textos em francês e teria sua entrada garantida em espaços consulares, informações não disponíveis no restante da correspondência de Eça, o que permite levantar a hipótese que lhe ocorreram no momento em que escrevia ao amigo, com o intuito de dar sustentação à sua argumentação.

Enquanto esperava notícias do novo posto, no dia 17 de agosto Eça escreveu para Jules Genelioux, possivelmente depois de receber o de acordo de Pina, tanto que a carta iniciava-se com um pedido de desculpas pela demora na resposta, sob o argumento de que havia esperado o parecer do sócio. Concordava que seria prudente acompanhar o desempenho da revista por alguns meses, mas confessava ainda não ter entendido plenamente a proposta dos editores no que respeitava à divisão das despesas. Assim, propunha que os custos de produção (colaboração, gravuras, papel, impressão, expedição e correio) fossem divididos entre todos os envolvidos, porém julgava que deveriam caber exclusivamente à casa os que dissessem respeito aos intermediários, sob o argumento de que o grosso do trabalho recaía nos ombros dos diretores. Eça remetia orçamento do impressor do Quai Voltaire para 3 mil exemplares que, por certo, havia sido obtido por Mariano. Quanto ao preço da revista, considerado alto por Genelioux, a argumentação caminhou no sentido de destacar os atributos do volume, com suas 128 páginas, impressão e papel de alta qualidade. Astutamente, o remetente sugeria que talvez fosse o caso de cobrar 600 réis o exemplar, ${ }^{54}$ cabendo lembrar que qualquer diminuição de preço colocaria em risco a contabilidade tão zelosamente elaborada.

É difícil precisar o momento exato que Eça teve certeza de sua nomeação para Paris, que foi publicada em 28 de agosto. $\mathrm{O}$ fato não foi referido na carta remetida a Genelioux no dia seguinte (29) e que contém o desfecho do projeto da revista, que sofreu considerável reviravolta. A carta abre-se com Eça comunicando ao editor o afastamento de Mariano Pina, em função de este haver assumido cargo que o obrigava a residir em Lisboa. $\mathrm{O}$ motivo alegado tem sido repetido pela bibliografia especializada, a despeito de Pina não haver se transferido para Lisboa. De fato, ele passou a integrar comissão responsável por preparar a participação

\footnotetext{
${ }^{53}$ Carta de Eça de Queirós para Oliveira Martins, remetida de Londres em 15/8/1888. Transcrita por CASTILHO, Guilherme de (Org.). Eça de Queirós. Correspondência, op. cit, p. 509-510. V. I.

${ }^{54}$ Carta de Eça de Queirós a Jules Genelioux, remetida de Londres em 17/8/1888. Transcrita por CAETANO, Marcello. Cartas de Eça de Queirós a seus editores (1887-1894), op. cit., p. 32-35.
} 
de Portugal na Exposição Universal de 1889, o que exigiu constantes deslocamentos à capital do país, como se pode acompanhar pelas notícias publicadas na revista Ilustração, que ele continua a dirigir, mas é certo que residiu em Paris até fins de 1890.

$\mathrm{Na}$ correspondência disponível, não há qualquer menção sobre o afastamento de Pina da projetada revista, ainda que eles continuassem a trocar cartas entre o final de agosto e o início de setembro, como indica o fato de se contar com respostas de Eça datadas do dia 2 e 19 de setembro. A temática, entretanto, relacionava-se à tumultuada posse do novo cônsul em Paris, que só se efetivou em 30 do referido mês e foi antecedida por cena rocambolesca, que exigiu a intervenção da polícia. ${ }^{55} \mathrm{O}$ tom é de cordialidade e o escritor conta com Pina para defendê-lo na imprensa lisboeta, o que sugere que a saída do diretor da Ilustração do projeto não abalou o relacionamento entre ambos.

$\mathrm{Na}$ carta remetida ao editor, Eça referiu-se brevemente à saída de Mariano para concentrar-se no essencial: as implicaçôes práticas para o empreendimento. E estas diziam respeito ao fato de a impressão não poder mais ser feita em Paris, já que não havia quem a supervisionasse e era justamente "essa supervisão e a impressão em Paris as principais causas da nossa [dele e de Pina] associação," e do abandono das ilustraçôes, pois "infelizmente é um fato conhecido que em Portugal não se pode imprimir gravuras com a nitidez e perfeição que eu desejaria”. Em contrapartida, ponderava que tudo ficaria mais simples com a produção concentrada num único lugar, como deve ter sugerido o editor, tanto que ele considerava que "sua proposição só oferece vantagens". ${ }^{6}$

A carta prossegue com detalhes sobre o pagamento aos colaboradores, mas o que importa reter é o fato de o escritor não estar disposto a dar prosseguimento à ideia primitiva, que implicaria cuidar pessoalmente de aspectos que eram da alçada de Pina, isso no exato momento em que se concretizava sua transferência para Paris. Os termos do acordo, no que se refere à remuneração, foram explicitados na carta seguinte, de 12 de setembro, na qual Eça concorda em receber um montante (náo especificado) sobre cada volume da revista, cabendo à casa as tarefas relativas à edição do periódico que, enfim, tinha nome próprio: Revista de Portugal. ${ }^{57}$

\footnotetext{
55 Sobre a questáo, ver: MATOS, A. Campos. Eça de Queirós. Uma biografia. Campinas, SP: Editora da Unicamp, 2014, p. 194.

${ }^{56}$ Carta de Eça de Queirós a Jules Genelioux, remetida de Londres em 29/8/1888. Transcrita por CAETANO, Marcello. Cartas de Eça de Queirós a seus editores (1887-1894), op. cit., p. 35-36. "Cette surveillance et le fait de l'impression à Paris étaient la principale cause de notre association"; "c'est malheureusement un fait avéré qu'on ne peut pas imprimer a Portugal les gravures avec la netteté er perfection que j’aurais désiré”; "votre proposition n'offre que des avantages".

${ }^{57}$ Carta de Eça de Queirós a Jules Genelioux, remetida de Bristol em 12/9/1888. Transcrita por CAETANO, Marcello. Cartas de Eça de Queirós a seus editores (1887-1894), op. cit., p. 41-42. O trecho exato é o seguinte: "Eu estou de acordo com a sua proposta - segundo a qual o senhor permanece no seu papel de editor e me paga um tanto sobre cada volume da Revista. Eu aceito." "Je suis d'accord avec votre proposition — par laquelle vous restez dans votre rôle d'éditeur et me payez un tant sur chaque volume de la Revue toute écrite. J'accepte donc.".
} 
A crise enfrentada pelo impresso em 1890 deu ensejo a novo acordo com os editores do Porto, como explicitou em carta à esposa em abril de 1890, que esclarece, de maneira mais detida, os meandros do acordo:

O Genelioux toma conta de todas as despesas; eu recebo um ordenado como diretor e a minha colaboração é paga a $2 \$ 000$ réis a página. Isto vale até que a Revista venha a ter 2.000 números de venda. Se chegarmos a esse desideratum voltamos ao antigo contrato, isto é, recebo além disso, um tanto por número. Em todo caso a Revista continua. As inovaçóes que se lhe fazem consistirão em a tornar mais congênere e adequada à mediocridade do púbico — que se não interessa por alta literatura, quer contos, viagens, biografias, etc. Nada do que ele gosta lhe recusaremos, a não ser as charadas. Vamos fazer uma circular para mandar a todo mundo pedindo assinaturas, etc. Enfim, tentar um esforço. ${ }^{58}$

\section{Conclusão}

A Revista de Portugal ocupa lugar importante na biografia de Eça de Queirós e a reconstrução dos seus bastidores é instrutiva em vários sentidos. De saída, evidenciam-se o seu senso prático e a habilidade no trato das questóes de ordem financeira que envolviam o lançamento de um periódico. É bem provável que as esperanças depositadas na associação com Mariano Pina tenham logo se esvaído, uma vez que o interlocutor parecia ter dificuldades em acompanhar a sua argumentação, sempre ancorada em cifras precisas. Pode-se supor que motivaçóes econômicas foram o mote do projeto, afinal, diretores e editores esperavam obter lucros com o empreendimento, o que implicava calcular meticulosamente a receita e a despesa.

No que se refere à primeira, observa-se certa ingenuidade dos proponentes, que sempre contaram com a colocação no mercado de, no mínimo, 2 mil exemplares. Talvez parte do otimismo derivasse da natureza da publicação que, pelos planos iniciais, seria um produto elegante, impresso com esmero em papel de alta qualidade e incorporando imagens, a grande novidade do momento, ainda que se distanciando do gênero inaugurado por The Illustrated London News, por se tratar de um volume com mais de cem páginas, em grande parte consagradas a ensaios e estudos. Era justamente a falta desse tipo de produto que, a baixo custo, só poderia ser produzido nas tipografias francesas, que infundia confiança nos diretores, que se fiavam em despesas relativamente modestas.

A solução arquitetada indica o grau de internacionalização do mundo dos impressos periódicos, não só em termos materiais, ou seja, relativos ao processo de fabricação de cada exemplar, mas também no que respeita à circulação de modelos e soluções, tanto que Eça

\footnotetext{
${ }^{58}$ Carta de Eça de Queirós à sua esposa, remetida do Porto em 7/4/1890, grifo no original. Transcrita por CASTILHO, Guilherme de (Org.). Eça de Queirós. Correspondência, op. cit., p. 58. v. II.
} 
expressava o desejo de dirigir uma revista que tivesse a repercussão e o prestígio da Revue des Deux Mondes, mas que também incorporasse as inovaçóes das publicaçóes britânicas, das quais era leitor assíduo, ${ }^{59}$ desse a conhecer a produção portuguesa e conectasse o país com o resto do mundo, ambiçóes expressas no programa-prospecto. $\mathrm{O}$ fato de ser uma mercadoria, com todas as implicaçôes que tal condição comporta, não retirava do impresso seu potencial de intervenção no espaço público, como revela a correspondência de Eça, que, com destreza, manejava a pena em função do interlocutor.

A circunstância de ter que se valer de tipografias portuguesas impôs significativas mudanças no formato original, afetando a concepção do projeto, cujo produto final tornou-se menos atrativo do que o planejado, fator que pode ter contribuído para seduzir número mais modesto de leitores. Era o que ele intuía ao afirmar, na mesma carta, já citada, para a esposa: "É evidente que ainda se pode ganhar dinheiro em Portugal com uma Publicação — mas ainda não descobri que natureza especial deve ter esta publicação. Suponho que um Magazine com pinturas é o que o público queria. Mas isso é difícil — por causa das pinturas." ${ }^{\circ 0}$

Seu trabalho à frente da Revista de Portugal, que se estendeu de julho 1889 a maio de 1892, constituiu-se um espaço privilegiado para avaliar a condição do intelectual no país, ainda preso às lides do serviço público e subordinado aos ditames do poder, e o gosto do diminuto público alfabetizado, pouco afeito às leituras densas. É muito provável que a experiência à frente da revista tenha contribuído para que recebesse convite de Ferreira de Araújo para dirigir o Suplemento literário da Gazeta de Notícias, que circulou de janeiro a junho de 1892, segunda experiência de Eça à testa de uma publicação, atividade que, entretanto, ultrapassa os propósitos deste artigo. ${ }^{61}$

\section{Referências bibliográficas}

ANDRADE, Joaquim Marçal Ferreira de. História da fotorreportagem no Brasil. A fotografia na imprensa do Rio de Janeiro de 1839 a 1900. Rio de Janeiro: Elsevier 2004.

ANDRADE, Luís Crespo. Introdução. Quatro notas breves. In: . (Coord.). Revistas. Ideias e Doutrinas. Lisboa: Livros Horizonte, 2003, p. 12.

ANDRADE, Miranda de. Eça de Queirós e a Revista de Portugal. Lisboa: Ediçóes da Revista Ocidente, 1953, p. 30.

\footnotetext{
${ }^{59}$ Sobre as leituras de Eça, ver: COELHO, Teresa Pinto, Londres em Paris. Eça de Queirós e a imprensa inglesa, op. cit., p.15-68.

${ }^{60}$ Carta de Eça de Queirós à sua esposa, remetida do Porto em 7/4/1890, grifo no original. Transcrita por CASTILHO, Guilherme de (org.). Eça de Queirós. Correspondência, op. cit., p. 58. v. II.

${ }^{61}$ A respeito do Suplemento, consultar, BONILHA, Juliana. Eça de Queirós e a Gazeta de Notícias. Suplemento Literário, 1892. Jundiaí, SP: Paco Editorial, 2015 e COELHO, Teresa Pinto, Londres em Paris. Eça de Queirós e a imprensa inglesa, op. cit., p. 137-198.
} 
BACOT, Jean-Pierre. La presse illustrée au XIXe siècle. Une histoire oubliée. Limoges: Presse Universitaires de Limoges, 2005.

BERNERON-COUVENHES, Marie-Françoise. Les Messageries Maritimes. L'essor d'une grande compagnie de navigation française, 1851-1894. Paris: Presse de l'Université ParisSorbonne, 2007.

BONILHA, Juliana. Eça de Queirós e a Gazeta de Notícias. Suplemento Literário, 1892. Jundiaí, SP: Paco Editorial, 2015.

CABRAL, Alexandre. Polêmicas de Castelo. Lisboa: Livros Horizonte, 1982, p. 167-187. v. VI. CAETANO, Marcello. Cartas de Eça de Queirós a seus editores (1887-1894). Lisboa: Panorama, 1961, p. 24.

CAMARGO, Katia Aly Franco de. A Revue des Deux Mondes: intermediária entre dois mundos. Natal: Editora da UFRN, 2007.

CARDOSO, Rafael. Projeto gráfico e meio editorial nas revistas ilustradas do Segundo Reinado. In: KNAUSS, Paulo; MALTA, Marize; OLIVEIRA, Cláudia; VELLOSO, Mônica Pimenta (Org.). Revistas Ilustradas. Modos de ler e ver no Segundo Reinado. Rio de Janeiro: Mauad X; FAPERJ, 2011, p. 17-40.

CASTILHO, Guilherme de (Org.). Eça de Queirós. Correspondência. Lisboa: Imprensa Nacional, Casa da Moeda, 1983, p. 466-468 e p. 477. v. I.

COELHO, Teresa Pinto. Londres em Paris. Eça de Queirós e a imprensa inglesa. Lisboa: Ediçôes Colibri, 2010, p. 16-136.

DOMINGOS, Manuela D. Estudos de sociologia da cultura. Livros e leitores do século XIX. Lisboa: Instituto Português de Ensino a Distância, 1985, p. 11-134.

DUTRA, Eliana de Freitas. The Revue des Deux Mondes on the context of transatlantic exchanges. In: ABREU, Márcia; SILVA, Ana Cláudia Suriani da. The cultural revolution on the nineteenth century. Theatre, the book-trade, and reading in the transatlantic world. Londres: I. B. Taurus, 2016, p. 121-138.

FARIA E ALBUQUERQUE, Isabel. Novos contributos para a correspondência de Eça de Queirós. Coimbra: Biblioteca Geral da Universidade de Coimbra, 1992, p. 84.

GESLOT, Jean-Charles; HAGE, Julien. Recenser les revues. In: PLUET-DESPATIN, Jacqueline; LEYMARIE, Michel; MOLLIER, Jean-Yves (Dir.). La Belle Époque des revues, 1880-1914. Ardenne: Éditions de L'EMEC, 2002, p. 29-42.

LOUÉ, Thomas. Un modèle matriciel: les revues de culture générale. In: PLUET-DESPATIN, Jacqueline; LEYMARIE, Michel; MOLLIER, Jean-Yves (Dir.). La Belle Époque des revues, 1880-1914. Ardenne: Éditions de L'EMEC, 2002, p. 57-68.

LUCA, Tania Regina de. Correspondente: origens da atividade no Brasil nas décadas de 1870 e 1880. Sobre jornalismo. Revista científica internacional, v. 5, n. 1, jan./jul. 2016.

Disponível em: <http://surlejournalisme.com/rev/index.php/slj>. 
MARTINS, Ana Luiza. Revistas em revista. Imprensa e práticas culturais em tempos de República. São Paulo (1890-1922). São Paulo: Edusp; Fapesp; Imprensa Oficial do Estado, 2001, p. 75-77.

MATOS, A. Campos. Eça de Queirós. Uma biografia. Campinas, SP: Editora da Unicamp, 2014, p. 194.

MINÉ, Elza. Mariano Pina, a Gazeta de Notícias e A Ilustração: histórias de bastidores contadas por seu espólio. Revista da Biblioteca Nacional, Lisboa, v. 7, n. 2, p. 23-61, jul./dez. 1992.

MOLLIER, Jean-Yves. $O$ dinheiro e as letras. História do capitalismo editorial. São Paulo: Edusp, 2010, p. 82-83.

OLIVEIRA, Lopes de. Eça de Queiróz. A sua vida e a sua obra. Lisboa: Ediçóes Excelsior, 1944, p. 243-252.

PINA, Mariano. Crônica. A Ilustração, Paris, ano 5, v. 5, n. 7, p. 98, 5/4/1888.

. Crônica. Eça e Zola. A Ilustração, Paris, ano 2, v. 2, n. 11, p. 162-163, 5/6/1885.

QUEIRÓS, Eça. Uma carta sobre Victor Hugo. A Ilustração, Paris, ano 2, v. 2, n. 16, p. 251, 253-254, 20/8/1885.

REIS, Carlos. Duas cartas inéditas de Eça de Queirós para Mariano Pina. Colóquio/Letras, Lisboa, n. 109, p. 80, maio/jun. 1989.

SANTOS, Renata. A imagem gravada. A gravura no Rio de Janeiro entre 1808 e 1853 . Rio de Janeiro: Casa da Palavra, 2008. 